\title{
PENGARUH CORPORATE GOVERNANCE TERHADAP TAX AVOIDANCE PADA PERUSAHAAN PERTAMBANGAN YANG TERDAFTAR DI BEI
}

\author{
Uun Sunarsih, Ade Refany Oktavia \\ Sekolah Tinggi Ilmu Ekonomi Indonesia (STEI) \\ E-mail:uun.sunarsih@yahoo.co.id
}

\begin{abstract}
$A B S T R A C T$
This study aims to examine the effect of corporate governance on tax a voidance. This research is conducted on mining companies listed in BEI period 2012-2015. The method used purposive sampling and obtained 10 companies. The data used is secondary data can be downloaded www.idx.co.id. The results of this study conclude ROA does not affect tax avoidance, because the company tries to obtain high profit as an indicator of company performance. Institutional ownership has no effect, it may not be able to supervise any management decision. Managerial ownership is influential, it is possible that managerial ownership can increase optimal supervision. The board of independent commissioners is influential, indicating the greater the composition of the commissioner the better the performance. Audit committee is influential, indicating the number of audit committees able to improve supervision on management. Audit quality influences indicates that the audit services used can reduce tax avoidance measures.
\end{abstract}

Keywords: Return On Asset, Corporate Governance Mechanism, Tax Avoidance

\section{PENDAHULUAN}

Pajak dipandang oleh perusahaan sebagai salah satu biaya yang harus dikeluarkan dan merugikan, karena sifatnya yang menjadi pengurang laba perusahaan (Permana, 2015). Untuk meminimalkan jumlah beban pajak yang harus dibayar,wajib Pajak biasanya melakukan manajemen pajak (tax management). Manajemen pajak terbagi menjadi dua, yaitu penghindaran pajak (tax avoidance) dan penggelapan pajak (tax evasion). Tax Avoidance merupakan usaha pengurangan pembayaran pajak secara legal. Sedangkan tax evasion merupakan usaha pengurangan pembayaran pajak secara ilegal (Budiman \& Setiyono, 2012).

Tax Avoidance menjadi cukup rumit karena disisi lain diperbolehkan karena tidak melanggar hukum, tetapi disisi lain dengan adanya tindakan penghindaran pajak tersebut penerimaan negara akan menjadi lebih sedikit dari yang seharusnya (Winata, 2014). Selain itu, Sari (2014) menjelaskan secara hukum tax avoidance tidak dilarang meskipun seringkali mendapatkan sorotan yang kurang baik dari kantor pajak karena dianggap memiliki konotasi negatif. Tax avoidance ini juga terkadang sering kali menimbulkan bias, yang mengakibatkan sebuah pemikiran apakah tax avoidance perlu dilakukan atau tidak.

Kegiatan tax avoidance akhir-akhir ini diperkirakan akan menjadi hal penting yang harus diperhatikan oleh fiskus. Praktik penghindaran pajak mungkin saja menjurus pada upaya penggelapan pajak, hal itu tentu akan memberikan efek negatif bagi negara, karena apabila dibiarkan terus-menerus akan menyebabkan negara menderita kehilangan pendapatan pajak dengan jumlah yang cukup signifikan dan akan memberikan dampak bagi pertumbuhan ekonomi negara Indonesia. Berdasarkan data perpajakan yang disampaikan oleh Direktorat Jenderal

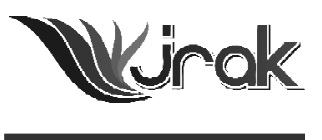

Jurnal Reviu Akuntansi dan Keuangan ISSN: 2088-0685 Vol. 6 No. 2, Oktober 2016 Pp 923-932 
Pengaruh

Corporate

Governance...

924
Pajak tahun 2012, terdapat 4000 perusahaan Penanaman Modal Asing yang melaporkan nihil nilai pajaknya, perusahaan tersebut diketahui ada yang mengalami kerugian selama 7 tahun berturut-turut dan umumnya perusahaan tersebut bergerak pada sektor manufaktur dan pengolahan bahan baku.

Perusahaan-perusahaan publik di Indonesia masih banyak yang melakukan tax avoidance.Hal ini membuktikan bahwa corporate governance(CG)belum dilakukan dengan maksimal (Maharani dan Suardana, 2014). CG adalah suatu sistem dan seperangkat peraturan yang mengatur hubungan antara pemegang saham, dewan komisaris, dan dewan direksi agar kinerja perusahaan dijalankan dengan efektif, efisien, transparan, dan akuntabel demi tercapainya tujuan organisasi dan menghindari kecurangan-kecurangan dalam manajemen perusahaan, selain itu juga dapat menghasilkan laporan keuangan yang akuntabel yang berguna bagi para penggunanya untuk mengambil keputusan (Santoso, 2014).Di Indonesia, telah dibentuk Komite Nasional Kebijakan Governance (KNKG) yang menghasilkan suatu pedoman dasar good corporate governance bagi semua perusahaan.Pedoman ini tidak memiliki kekuatan hukum yang mengikat namun merupakan rujukan bagi dunia usaha dalam menerapkan good corporate governance (KNKG, 2006). Semua perusahaan di Indonesia harus memastikan bahwa asas-asas good corporate governance telah diaplikasikan dalam perusahaan dengan baik dan efektifsehingga perusahaan dapat berkembang dan semakin besar.

Sampai saat ini CG merupakan isu yang menarik untuk terus dikaji pelaku bisnis, akademisi, pembuat kebijakan. Pandangan terhadap praktik corporate governance terus berkembang dari waktu ke waktu.CG menjadi tolak ukur kinerja suatu perusahaan. Selain itu, CG juga memastikan agar tata kelola perusahaan dalam perpajakan tetap berada dalam koridor penghindaran pajak yang bersifat legal bukan penggelapan pajak yang bersifat ilegal. Penerapan CG dilatar belakangi oleh struktur yang terdapat pada perusahaan.

Struktur kepemilikan perusahaan terdiri dari kepemilikan institusional dan kepemilikan manajerial. Kepemilikan institusional berperan penting dalam mengawasi kinerja manajemen yang lebih optimal, sedangkan kepemilikan manajerial berperan dalam menghilangkan permasalahan keagenan jika diasumsikan seorang manajer sekaligus sebagai seorang pemilik. Mekanisme dalam pengawasan CG ada internal dan eksternal. Mekanisme internal adalah cara untuk mengendalikan perusahaan dengan menggunakan struktur dan proses internal seperti Rapat Umum Pemegang Saham (RUPS), komposisi dewan direksi, proporsi dewan komisaris dan pertemuan dengan board of director, sedangkan mekanisme eksternal adalah seperti pengendalian oleh perusahaan, struktur kepemilikan, dan pengendalian pasar (Fadhilah, 2014). Pada penelitian ini, penerapan corporate governance akan dilihat dari mekanismenya dengan proksi dewan komisaris independen, komite audit dan kualitas audit.

Dewan komisaris independen merupakan komisaris yang tidak berasal dari pihak terafiliasi. Pengertian terafiliasi adalah pihak yang mempunyai hubungan bisnis dan kekeluargaan dengan pemegang saham pengendali, anggota direksi dan dewan komisaris lain, serta dengan perusahaan itu sendiri (KNKG, 2006). Dengan adanya dewan komisaris independen diharapkan dapat meningkatkan pengawasaan sehingga dapat mencegah agresifitas pajak perusahaan yang dilakukan oleh manajemen (Fadhilah, 2014). Komite audit dalam bidang CG bertanggung jawab untuk memastikan bahwa perusahaan telah dijalankan sesuai undangundang dan peraturan yang berlaku, melaksanakan usahanya dengan beretika, melaksanakan pengawasannya secara efektif terhadap benturan kepentingan dan kecurangan yang dilakukan oleh karyawan perusahaan. Sedangkan, kualitas audit pengukurannya dapat dilakukan dengan menggunakan proksi spesialisasi industri dan ukuran KAP.Annisa dan Kurniasih (2012), memberikan suatu pandangan mengenai keterkaitan CG terhadap tindakan penghindaran pajak, jika CG dalam perusahaan dijalankan dengan pengawasan yang baik, maka perusa- 
haan tersebut bisa dikatakan memiliki tata kelola perusahaan yang baik termasuk salah satunya dalam hal memenuhi kewajiban pajaknya.

Penelitian yang terkait dengan tax avoidance telah banyak dilakukan, diantaranya dilakukan oleh Annisa dan Kurniasih (2012), Fadhilah (2014), Maharani dan Suardana (2014),Puspita dan Harto (2014) dan Sunarsih \& Oktaviani (2016).Perbedaan hasil penelitian tersebut menjadi motivasi untuk meneliti kembali. Perbedaan dalam penelitian ini adalah mengembangkan penelitian yang sudah dilakukan Sunarsih dan Oktaviani (2016) dengan menambahkan variable ROA(Maharani dan Suardana, 2014). Dalam penelitian ini, CG diproksikan dengan kepemilikan institusional, kepemilikan manajerial dewan komisaris independen, komite audit, dan kualitas audit yang berasal dari penelitian Sunarsih dan Oktaviani (2016) dan Return On Asset. Perbedaan yang kedua adalah variable tax avoidance dalam penelitian ini diproksikan dengan Current Effective Tax Rate(Current ETR), sedangkan penelitian Sunarsih dan Oktaviani (2016) menggunakan book tax gap.

Berdasarkan latar belakang tersebut maka pertanyaan penelitian adalah: (1) Apakah Return On Asset berpengaruh terhadap tindakan tax avoidance? (2) Apakah kepemilikan institusional berpengaruh terhadap tindakan tax avoidance? (3) Apakah kepemilikan manajerial berpengaruh terhadap tindakan tax avoidance? (4) Apakah dewan komisaris independen berpengaruh terhadap tindakan tax avoidance? (5) Apakah komite audit berpengaruh terhadap tindakan tax avoidance? (6) Apakah kualitas audit berpengaruh terhadap tindakan tax avoidance?

Penelitian ini bertujuan untuk mengetahui pengaruh Return On Asset, kepemilikan institusional, kepemilikan manajerial, dewan komisaris independen, komite audit,kualitas audit terhadap tax avoidance pada perusahaan pertambangan yang terdaftar di Bursa Efek Indonesia periode 2012-2015.

\section{METODE}

Penelitian ini merupakan penelitian kuantitatif dengan menggunakan data sekunder yaitulaporan tahunandan laporan keuangan perusahaan pertambangan yang terdaftar di Bursa Efek Indonesia tahun 2012-2015 yang dapat diakses melalui website resmi Bursa Efek Indonesia, yaitu www.idx.co.id.

Populasi dalam penelitian ini adalah perusahaan pertambangan yang terdaftar di Bursa Efek Indonesia tahun 2012-2015. Sampel dalam penelitian ini diperoleh menggunakan metode purposive sampling dengan berdasarkan kriteriakriteria yang telah ditentukan, yaitu (1) perusahaan pertambangan yang terdaftar di Bursa Efek Indonesia periode 2012-2015, (2) perusahaan pertambangan yang mempublikasikan laporan tahunan dan laporan keuangan secara lengkap dan konsisten pada tahun 2012-2015, (3) perusahaan terdaftar di Bursa Efek Indonesia dari awal periode pengamatan dan tidak delisting sampai akhir periode pengamatan, (4) perusahaan pertambangan yang pada tahun 2012-2015 tidak mengalami kerugian sebelum pajak, (5) nilai Current Effective Tax Rate (Current ETR) harus bernilai positif dan tidak lebih dari 1, sebab perusahaan dengan nilai $\mathrm{Cur}^{-}$ rent ETR lebih dari 1 mengindikasikan semakin rendah tingkat penghindaran pajak perusahaan. Berdasarkan kriteria tersebut, diperoleh 10 perusahaan pertambangan yang memenuhi kriteriayang diamati selama 4 tahun, yaitu tahun 2012-2015. Untuk menguji hipotesis maka dibuat model yang menjelaskan hubungan antar variable yang akan diteliti. Model disusun menggunakan persamaan regresi berganda sebagai berikut:

CURRENT_ETR $=\alpha+\beta_{1} \mathrm{ROA}_{\mathrm{it}}+\beta_{2} \mathrm{KI}_{\mathrm{it}}+\beta_{3} \mathrm{KM}_{\mathrm{it}}+\beta_{4} \mathrm{DKI}_{\mathrm{it}} \beta_{5} \mathrm{KOA}_{\mathrm{it}}+\beta_{6} \mathrm{KUA}_{\mathrm{it}} \varepsilon$ 


$\begin{array}{lll}\text { Pengaruh } & \text { Keterangan: } & \\ \text { Corporate } & \text { CURRENT_ETR } & \text { : Current ETR(proksi tax avoidance) } \\ \text { Governance... } & \alpha & : \text { Konstanta } \\ & \text { ROA } & : \text { Return On Asset } \\ & \text { KI } & : \text { Kepemilikan Institusional } \\ 926 & \text { KM } & : \text { Kepemilikan Manajerial } \\ & \text { DKI } & : \text { Dewan Komisaris Independen } \\ & \text { KOA } & : \text { Komite Audit } \\ & \text { KUA } & : \text { Kualitas Audit } \\ & \beta_{1}, \ldots, \beta_{6} & : \text { Koefisien Regresi } \\ & \varepsilon & : \text { Variabel Pengganggu (error) }\end{array}$

Variabel dependen dalam penelitian ini adalahtax avoidance. Pengukuran variabel tax avoidance dalam penelitian ini dilakukan dengan menggunakan proksi Current Effective Tax Rate (Current ETR). Current ETR dihitung dengan membandingkan pajak kini (current tax) dengan laba sebelum pajak penghasilan (pretax income). (Tandean, 2014). Variabel tax avoidance ini diukur dengan menggunakan rumus sebagai berikut:

$$
\text { Current ETR }=\frac{\text { Current Tax Expense }}{\text { Pre }- \text { Tax Income }}
$$

Return On Asset (ROA) merupakan kemampuan perusahaan dalam menghasilkan laba. Dalam penelitian ini diukur dengan perbandingan antara laba bersih dengan total aset pada akhir periode. Variabel ini telah dijadikan variable penelitian oleh Maharani dan Suardana (2014). Variabel ROA diukur dengan menggunakan rumus sebagai berikut:

$$
R O A=\frac{\text { Laba Bersih Setelah Pajak }}{\text { Total Asset }} \times 100 \%
$$

Kepemilikan Institusional (KI) adalah jumlah kepemilikan saham yang dimiliki oleh pihak institusi.Kepemilikan Institusional dalam penelitian ini diukur menggunakan persentase kepemilikan saham perusahaan yang dimiliki oleh institusi dari seluruh jumlah saham yang beredar. Variabel ini telah dijadikan variabel penelitian oleh Annisa dan Kurniasih (2012), Fadhilah (2014), Sunarsih dan Oktaviani (2016) dengan menggunakan rumus:

$$
K I=\frac{\text { Jumlah Saham yang Dimiliki Institusi }}{\text { Jumlah Seluruh Saham yang Beredar }}
$$

Kepemilikan Manajerial (KM) dalam penelitian ini diukur menggunakan persentase kepemilikan saham perusahaan yang dimiliki oleh pihak manajemen dari seluruh jumlah saham yang beredar. Variabel ini telah dijadikan variabel penelitian oleh Annisa dan Kurniasih (2012), Sunarsih dan Oktaviani (2016) dengan menggunakan rumus:

$$
K M=\frac{\text { Jumlah Saham yang Dimiliki Manajemen }}{\text { Jumlah Seluruh Saham yang Beredar }}
$$

Dewan Komisaris Independen (DKI) dapat diartikan sebagai pihak yang tidak memiliki afiliasi dengan pemegang saham pengendali, direksi atau dewan komisaris internal serta tidak menjabat sebagai direktur pada suatu perusahaan yang terkait.Dalam penelitian ini variabel struktur dewan komisaris diproksikan dengan persentase keberadaan dewan komisaris independen dalam suatu perusa- 
haan.Variabel ini telah dijadikan variabel penelitian oleh Fadhilah (2014), dan Sunarsih dan Oktaviani (2016) dengan menggunakan rumus sebagai berikut:

$$
D K I=\frac{\text { Jumlah Anggota Dewan Komisaris Independen }}{\text { Jumlah Seluruh Anggota Dewan Komisaris }}
$$

Komite Audit (KOA) dalam suatu perusahaan berperan dalam memberikan pandangan mengenai masalah-masalah yang berhubungan dengan kebijakan keuangan, akuntansi dan pengendalian intern. Variabel ini telah dijadikan variabel penelitian oleh Fadhilah (2014) dan Sunarsih dan Oktaviani (2016). Komite Audit (KOA) dalam penelitian ini diukur dengan menggunakan jumlah komite audit dalam suatu perusahaan.

\section{KOA = Jumlah Komite Audit}

Kualitas Audit (KUA) dapat diukur dengan menggunakan proksi ukuran Kantor Akuntan Publik (KAP) yang melakukan audit pada suatu perusahaan. Jika perusahaan diaudit oleh Kantor Akuntan Publik (KAP) The Big Four, maka akan lebih independen karena lebih dapat bertahan dari tekanan manajer untuk melaporkan adanya pelanggaran. Dalam penelitian ini, perusahaan yang diaudit oleh Kantor Akuntan Publik (KAP) The Big Four yaitu Price Waterhouse Cooper (PWC), Deloitte Touche Tohmatsu, KPMG, Ernst \& Young (E\&Y) akan diberi nilai 1, dan apabila tidak diaudit oleh keempat Kantor Akuntan Publik (KAP) di bawah lisensi KAP The Big Four akan diberi nilai 0.

Data dalam penelitian ini diolah dan dianalisis menggunakan software SPSS. Metode statistic yang digunakan untuk menguji hipotesis dalam penelitian ini adalah menggunakan metode regresi linear berganda untuk menguji hubungan antara variabel independen dan variable dependen.

\section{HASIL DAN PEMBAHASAN}

Uji normalitas dalam penelitian ini, diuji dengan menggunakan grafik histogram dan grafik Normal P-Plot. Hasil uji normalitas menunjukkan bahwa variabel yang digunakan dalam penelitian ini terdistribusi normal. Uji multikolinearitas dilakukan dengan menganalisis korelasi antar variable dengan menggunakan perhitungan nilaitolerancedan nilai variance inflationfactor (VIF). Hasil uji multikolinearitas menunjukkan bahwa tidak ada variabel independen yang memiliki nilai tolerance kurang dari 0,10 dan nilai VIF lebih dari 10. Sehingga dapat disimpulkan bahwa tidak terjadi multikolinearitas antar variabel independen dalam model regresi. Uji heteroskedastisitas dilakukan dengan analisis grafik scatterplot. Hasil grafik scatterplot menunjukkan titik-titik yang menyebar secara acak serta tersebar baik di atas maupun di bawah angka 0 pada sumbu Y. Hal ini dapat disimpulkan bahwa tidak terjadi heteroskedastisitas pada model regresi. Uji autokorelasi dilakukan dengan menggunakan uji Durbin Watson. Hasil uji autokorelasi menunjukkan nilai Durbin-Watson (DW hitung) sebesar 1,464. Nilai DW hitung tersebut berada di antara -2 dan +2 , yaitu $-2 \leq 1,464 \leq 2$ yang berarti tidak ada autokorelasi antar data runtut waktu dalam penelitian ini.

Berdasarkan uji koefisien determinasi diperoleh nilai Adjusted $R$-Square sebesar 0,857 . Hal ini menandakan bahwa $85,7 \%$ dari variasi variabeltax avoidance dapat dijelaskan oleh variabel return on asset, kepemilikan institusional, kepemilikan manajerial, dewan komisaris independen, komite audit, dan kualitas audit. Sedangkan sisanya sebesar 14,3\% dijelaskan oleh variabel-variabel lain yang tidak dimasukkan dalam model regresi. Analisis regresi linear berganda digunakan untuk mendapat koefisien regresi yang akan menentukan apakah hipotesis yang dibuat akan diterima atau ditolak. Maka diperoleh persamaan sebagai berikut: 


\section{Pengaruh \\ Corporate \\ Governance...}

928

Tabel 3

Hasil Uji Koefisien Determinasi Model Regresi 2

$$
\begin{aligned}
\text { CURRENT }_{E T R} & =0,394-0,305 \mathrm{ROA}-0,167 \mathrm{KI}+0,478 \mathrm{KM}+0,189 \mathrm{DKI} \\
& -0,046 \mathrm{KOA}+0,128 \mathrm{KUA}
\end{aligned}
$$

Uji-t untuk mengetahui apakah variabel independen mempunyai pengaruh secara parsial terhadap variabel dependen. Hasil uji-t dalam penelitian ini dapat dijelaskan sebagai berikut:

Variabel Return On Asset memiliki nilai signifikansi 0,075 yang lebih besar dari 0,05. Hal ini menunjukkan bahwa hipotesis pertama ditolak yang memiliki arti bahwa variabel return on asset tidak berpengaruh terhadap tax avoidance. Selanjutnya adalah variabel kepemilikan institusional memiliki nilai signifikansi 0,115 yang lebih besar dari 0,05. Hal ini menunjukkan bahwa hipotesis kedua ditolak yang berarti variabel kepemilikan institusional tidak berpengaruh terhadap tindakan tax avoidance. Variabel kepemilikan manajerial memiliki nilai signifikansi 0,040 yang lebih kecil dari 0,05. Hal ini menunjukkan bahwa hipotesis ketiga diterima yang memiliki arti bahwa variabel kepemilikan manajerial berpengaruh terhadap tax avoidance

Variabel dewan komisaris independen memiliki nilai signifikansi 0,003 yang lebih kecil dari 0,05. Hal ini menunjukkan bahwa hipotesis keempat diterima yang memiliki arti bahwa variabel dewan komisaris independen berpengaruh terhadap tax avoidance. variabel komite audit memiliki nilai signifikansi 0,047 yang lebih kecil dari 0,05. Hal ini menunjukkan bahwa hipotesis kelima diterima yang memiliki arti bahwa variabel komite audit berpengaruh terhadap tax avoidance.Dan terakhir adalah variabel kualitas audit memiliki nilai signifikansi 0,000 yang lebih kecil dari 0,05 . Hal ini menunjukkan bahwa hipotesis keenam diterima yang memiliki arti bahwa variabel kualitas audit berpengaruh terhadap tax avoidance.

\section{Pengaruh Return On Asset terhadap Tindakan Tax Avoidance}

Hipotesis pertama menyebutkan bahwa variabel return on asset berpengaruh terhadap tax avoidance.Hasil pengujian menunjukkan bahwa tingkat signigikan 0,075 lebih besar dari $\alpha=0,05$. Maka hasil tersebut menunjukkan bahwa hipotesis pertama yang menyatakan bahwa retun on asset berpengaruh terhadap tax avoidance ditolak. Hasil ini menunjukkan bahwa tidak terdapat pengaruh antara kemampuan menghasilkan laba perusahaan dengan penghindaran pajak perusahaan. Penghindaran pajak yang dilakukan dengan cara menurunkan pre-tax income (laba sebelum pajakpenghasilan) dapat membuat beban pajak perusahaan menjadi rendah. Namun semua perusahaan berupaya untuk memperoleh laba yang tinggi, karena profitabilitas perusahaan yang besar mengindikasikan kinerja perusahaan baik. Sehingga perusahaan memilih untuk tidak melakukan penghindaran pajak dengan menurunkan pre-tax income (laba sebelum pajak penghasilan), karena hal itu akan menurunkan ROA perusahaan yang mengindikasikan kinerja perusahaan kurang baik.

Hasil penelitian ini mendukung hasil penelitian yang dilakukan oleh Hadi \& Mangoting (2014) yang menyatakan bahwa return on asset tidak berpengaruh terhadap tax avoidance. Namun, hasil penelitian ini bertentangan dengan hasil penelitian yang dilakukan oleh Darmawan \& Sukartha (2014) yang menyatakan bahwa return on asset berpengaruh positif terhadap tindakan tax avoidance.

\section{Pengaruh Kepemilikan Institusional terhadap Tindakan Tax Avoidance}

Hipotesis kedua menyebutkan bahwa variabel kepemilikan institusional berpengaruh terhadap tax avoidance.Hasil pengujian menunjukkan bahwa tingkat signifikan 0,115 lebih besar dari $\alpha=0,05$. Maka hasil tersebut menunjukkan bahwa hipotesis kedua yang menyatakan bahwa kepemilikan institusional berpengaruh terhadap tax avoidance ditolak. Hasil ini menunjukkan bahwa adanya kepemilikan institusional dalam perusahaan tidak dapat dijadikan sebagai alat monitoring 
dalam setiap keputusan yang diambil pihak manajemen. Sehingga manajemen masih dapat melakukan tindakan-tindakan yang dapat menguntungkan dirinya sendiri.

Hasil penelitian ini mendukung hasil penelitian yang dilakukan oleh Annisa \& Kurniasih (2012), Fadhilah (2014), dan Sunarsih dan Oktaviani (2016). Penelitian-penelitian tersebut menyatakan bahwa kepemilikan institusional tidak berpengaruh terhadap tax avoidance. Akan tetapi, hasil penelitian ini bertentangan dengan hasil penelitian yang dilakukan oleh Sihaloho \& Pratomo (2015) yang menyatakan bahwa kepemilikan institusional berpengaruh negatif terhadap tax avoidance.

\section{Pengaruh Kepemilikan Manajerial terhadap Tindakan Tax Avoidance}

Hipotesis ketiga yang menyatakan bahwa kepemilikan manajerial berpengaruh terhadap tindakan tax avoidance. Hasil pengujian menunjukkan bahwa tingkat signifikan 0,040 lebih kecil dari $\alpha=0,05$. Maka hasil tersebut menunjukkan bahwa hipotesis ketiga yang menyatakan bahwa kepemilikan manajerial berpengaruh terhadap tax avoidance diterima. Hasil penelitian ini menunjukkan bahwa variabel kepemilikan manajerial dalam perusahaan mampu meningkatkan pengawasan yang optimal, sehingga mampu mempengaruhi pihak manajemen dalam melakukan kebijakan dalam tax avoidance. Hasil penelitian ini sesuai dengan hasil penelitian yang dilakukan oleh Sunarsih dan Oktaviani (2016) yang menemukan kepemilikan manajerial berpengaruh negatif terhadap penghindaran pajak.

\section{Pengaruh Dewan Komisaris Independen terhadap Tindakan Tax Avoidance}

Hipotesis keempat yang menyatakan bahwa dewan komisaris independen berpengaruh terhadap tindakan tax avoidance. Berdasarkan hasil pengujian, variabel dewan komisaris independen nilai signifikansi 0,003 yang lebih kecil dari 0,05 . Hal ini menunjukkan bahwa hipotesis keempat diterima yang memiliki arti bahwa variabel dewan komisaris independen berpengaruh terhadap tax avoidance. Hasil ini menunjukkan bahwa kinerja dewan komisaris independen yang ada di dalam perusahaan dapat mengurangi tindakan penghindaran pajak. Hal ini dimungkinkan bahwa semakin banyak dewan komisaris, maka maka semakin efektif kinerja mereka dalam melakukan pengawasan dan pengendalian terhadap kinerja direksi atau manajer dalam pengelolan perusahaan. Hasil penelitian ini mendukung hasil penelitian yang dilakukan oleh Annisa dan Kurniasih (2012), Fadhilah (2014), dan Puspita dan Harto (2014) yang menyatakan dewan komisaris independen berpengaruh negatif terhadap tax avoidance.

\section{Pengaruh Komite Audit terhadap Tindakan Tax Avoidance}

Hipotesis kelima yang menyatakan bahwa komite audit berpengaruh terhadap tindakan tax avoidance. Berdasarkan hasil pengujian, variabel komite audit memiliki nilai signifikansi 0,047 lebih kecil dari 0,05. Hal ini menunjukkan bahwa hipotesis kelima diterima yang memiliki arti bahwa variabel komite audit berpengaruh terhadap tax avoidance. Hasil ini menunjukkan bahwa semakin banyak jumlah komite audit pada suatu perusahaan akan meningkatkan kualitas tata kelola perusahaan, serta dapat meminimalisir praktik tax avoidance yang dilakukan pada perusahaan tersebut. Keputusan Ketua BAPEPAM dan Lembaga Keuangan Nomor: KEP-643/BL/2012 menetapkan komite audit terdiri dari paling kurang 3 (tiga) orang anggota yang berasal dari komisaris independen dan pihak dari luar perusahaan, jika jumlah komite audit kurang dari 3 orang maka tidak sesuai dengan peraturan BAPEPAM dan Lembaga Keuangan, sehingga akan meningkatkan tindakan manajemen dalam melakukan minimalisasi laba untuk kepentingan pajak. Selain itu, perusahaan yang memiliki komite audit akan lebih 
Pengaruh

Corporate

Governance...

930 bertangung jawab dan terbuka dalam menyajikan laporan keuangannya, karena komite audit akan memonitor segala kegiatan yang berlangsung di dalam perusahaan.

Hasil penelitian ini mendukung hasil penelitian yang dilakukan oleh Winata (2014), serta Maharani \& Suardana (2014) yang menyatakan bahwa komite audit berpengaruh negatif terhadap tax avoidance. Akan tetapi, hasil penelitian ini bertentangan dengan hasil penelitian yang dilakukan oleh Fadhilah (2014) dan Oktaviani (2016) yang menyatakan bahwa komite audit memiliki pengaruh positif dan signifikan terhadap tax avoidance. Penelitian-penelitian tersebut membuktikan bahwa semakin sedikit komite audit yang dimiliki oleh suatu perusahaan, maka pengendalian kebijakan keuangan yang dilakukan oleh komite audit sangat minim sehingga akan meningkatkan tindakan manajemen dalam melakukan tindakan penghindaran pajak. Dan kemungkinan komite audit dalam perusahaan tersebut ikut membantu manajemen dalam melakukan tindakan penghindaran pajak.

\section{Pengaruh Kualitas Audit terhadap Tindakan Tax Avoidance}

Hipotesis keenam yang menyatakan bahwa kualitas audit berpengaruh terhadap tindakan tax avoidance. Berdasarkan hasil pengujian, variabel kualitas audit memiliki nilai signifikansi 0,000 lebih kecil dari 0,05. Hal ini menunjukkan bahwa hipotesis keenam diterima yang memiliki arti bahwa variabel kualitas audit berpengaruh terhadap tax avoidance. Hasil ini menunjukkan bahwa perusahaan yang memakai jasa audit KAP The Big Four memiliki kemungkinan bahwa manajemen tidak melakukan penghindaran pajak. Hasil penelitian ini bertentangan dengan hasil penelitian yang dilakukan oleh Annisa dan Kurniasih (2012) yang menemukan bahwa kualitas audit berpengaruh positif terhadap penghindaran pajak. Namun hasil ini mendukung penelitian yang dilakukan oleh Fadhilah (2014) yang menemukan bahwa kualitas audit berpengaruh negatif terhadap tax avoidance.

\section{SIMPULAN}

Hasil penelitian ini menyimpulkan bahwa variabel return on asset tidak berpengaruh terhadap tax avoidance.Hal ini dikarenakan setiap perusahaan akan berusaha untuk memperoleh laba yang tinggi sebagai indikator kinerja perusahaan, sehingga perusahaan akan memilih untuk tidak melakukan penghindaran pajak dengan menurunkan laba sebelum pajak penghasilan. Variabel kepemilikan institusional tidak berpengaruh terhadap tax avoidance. Hal ini dimungkinkan bahwa kepemilikan institusional dalam perusahaan tidak dapat sebagai alat monitoringsetiap keputusan yang diambil. Variabel kepemilikan manajerial memiliki pengaruh terhadap penghindaran pajak. Hal ini mungkinkan bahwa kepemilikan manajerial mampu meningkatkan pengawasan optimal, sehingga mampu mempengaruhi manejemen untuk tidak melakukan penghindaran pajak. Variabel dewan komisaris independen memiliki pengaruh terhadap tax avoidance. Hal ini menunjukkan bahwa semakin besar komposisi komisaris, maka semakin baik kinerjanya dalam pengawasan dan pengendalian kinerja manajemen.Komite audit memiliki pengaruh terhadap tax avoidance. Hasil ini menunjukkan bahwa besar kecilnya jumlah komite audit dalam perusahaan mampu meningkatkan pengawasan pada manajemen, sehingga tidak melakukan penghindaran pajak. Kualitas audit memiliki pengaruh terhadap tax avoidance. Hasil ini menunjukkan bahwa jasa audit yang dipakai yaitu KAP The Big Fourdapat dimungkinkan menurunkan tindakan penghindaran pajak. 
Annisa, N.A. and L. Kurniasih. 2012. "Pengaruh Corporate Governance terhadap Tax Avoidance”. Jurnal Akuntansi \& Auditing. Vol. 8 No. 2. Hlm. 95-189.

Budiman, J. and Setiyono. 2012. "Pengaruh Karakteristik Eksekutif terhadap Penghindaran Pajak". Proceeding Simposium Nasional Akuntansi VX Banjarmasin, 1-22.

Darmawan, I.G.H. and I.M. Sukartha. 2014. "Pengaruh Penerapan Corporate Governance, Leverage, Return On Assets, dan Ukuran Perusahaan pada Penghindaran Pajak”. E-Jurnal Akuntansi Universitas Udayana. Vol. 1. Hlm. 143-161.

Fadhilah, R. 2014. "Pengaruh Good Corporate Governance terhadap Tax Avoidance (Studi Empiris Pada Perusahaan Manufaktur yang Terdaftar di BEI 2009-2011)". E-Jurnal Akuntansi Universitas Negeri Padang. Vol. 2. No.1.

Hadi, J. and Y. Mangoting. 2014. "Pengaruh Struktur Kepemilikan dan Karakteristik Dewan terhadap Agresivitas Pajak". Tax \& Accounting Review. Vol. 4. No. 2. hlm. 1-10.

KNKG (Komite Nasional Kebijakan Governance). 2006. "Pedoman Umum Good Corporate Governance Indonesia". www.bapepam.go.id.

Maharani, IG.A.C. and K.A. Suardana 2014. "Pengaruh Corporate Governance, Profitabilitas, dan Karakteristik Eksekutif pada Tax Avoidance Perusahaan Manufaktur”. E-jurnal Akuntansi Universitas Udayana 9.2, hlm 525-539.

Oktaviani, H.D. 2016. "Pengaruh Ukuran Dewan Direksi, Proporsi Dewan Komisaris Independen, dan Ukuran Komite Audit terhadap Praktik Manajemen Laba pada Perusahaan Farmasi yang Terdaftar di BEI Tahun 2009-20014”. E-jurnal Akuntansi universitas negeri Surabaya.Vol. 4. No. 2.

Permana, D. 2015. "Pengaruh Tenur Audit, Reputasi KAP dan Komite Audit Terhadap Kualitas Laba (Studi Empiris pada Perusahaan Manufaktur yang Terdaftar di BEI Periosde 2010-2013)". Jurnal WRA. Vol. 3 No. 2. Hlm.655672

Puspita, S.R. and P. Harto. 2014. "Pengaruh Tata Kelola Perusahaan terhadap Penghindaran Pajak". Diponegoro Journal of Accounting. Vol. 3. No. 2. Hlm. $1-13$.

Santoso, T.B. 2014. "Pengaruh Corporate Governance terhadap Penghindaran Pajak Perusahaan". Diponegoro Journal of Accounting. Vol. 3. Hlm. 1-37.

Sari, G.M. 2014. "Pengaruh Corporate Governance, Ukuran Perusahaan, Kompensasi Rugi Fiskal, dan Struktur Kepemilikan terhadap Tax Avoidance (Studi Empiris pada Perusahaan Manufaktur yang Terdaftar di BEI Tahun 2008-2012)". Jurnal Ekonomi Universitas Negeri Padang. Sumatera Barat.

Sihaloho, S.L. and D. Pratomo. 2015. "Pengaruh Corporate Governance dan Karakteristik Eksekutif terhadap Tax Avoidance". E-proceeding of Management. Vol. 2. No. 3.

Sunarsih, U. and K. Oktaviani. 2016. "Good Corporate Governance In Manufacturing Companies Tax Avoidance”. Jurnal Etikonomi. Vol. 15. No. 2. Hlm. 8596.

Tandean, V.A. 2014. "Pengaruh Good Corporate Governance dan Ukuran Perusahaan terhadap Tax Avoidance". Proceeding Seminar Nasional Multi Disiplin Ilmu \& Call For Paper UNISBANK.

Winata, F. 2014. "Pengaruh Corporate Governance terhadap Tax Avoidance pada Perusahaan yang Terdaftar di Bursa Efek Indonesia Tahun 2013”. Tax \& Accounting Review. Vol. 4. No. 1. hlm. 1-11. 
